\title{
Silver Modified Cathodes for Solid Oxide Fuel Cells
}

\author{
Sažinas, Rokas; Andersen, Kjeld Bøhm; Simonsen, Søren Bredmose; Holtappels, Peter; Kammer \\ Hansen, Kent
}

Published in:

Journal of The Electrochemical Society

Link to article, DOI:

10.1149/2.0361902jes

Publication date:

2019

Document Version

Publisher's PDF, also known as Version of record

Link back to DTU Orbit

Citation (APA):

Sažinas, R., Andersen, K. B., Simonsen, S. B., Holtappels, P., \& Kammer Hansen, K. (2019). Silver Modified Cathodes for Solid Oxide Fuel Cells. Journal of The Electrochemical Society, 166(2), F79-F88.

https://doi.org/10.1149/2.0361902jes

\section{General rights}

Copyright and moral rights for the publications made accessible in the public portal are retained by the authors and/or other copyright owners and it is a condition of accessing publications that users recognise and abide by the legal requirements associated with these rights.

- Users may download and print one copy of any publication from the public portal for the purpose of private study or research.

- You may not further distribute the material or use it for any profit-making activity or commercial gain

- You may freely distribute the URL identifying the publication in the public portal 


\title{
Silver Modified Cathodes for Solid Oxide Fuel Cells
}

\author{
Rokas Sažinas, $\mathbb{1}^{\mathrm{z}}$ Kjeld Bøhm Andersen, Søren Bredmose Simonsen, Peter Holtappels, ${ }^{*}$ \\ and Kent Kammer Hansen $(\mathbb{0}$
}

Department of Energy Conversion and Storage, Technical University of Denmark, DK-4000 Roskilde, Denmark

$\mathrm{La}_{1-\mathrm{x}-\mathrm{y}} \mathrm{Sr}_{\mathrm{x}} \mathrm{Ag}_{\mathrm{y}} \mathrm{MnO}_{3-\delta}$ was synthesized via modified Pechini method. Silver (Ag) was incorporated into $\mathrm{La}_{1-\mathrm{x}-\mathrm{y}} \mathrm{Sr}_{\mathrm{x}} \mathrm{Ag}_{\mathrm{y}} \mathrm{MnO}_{3-\delta} \mathrm{cathode}$ material for solid oxide fuel cells as a catalyst precursor for oxygen reduction reaction. The $\mathrm{La}_{1-x-y} \mathrm{Sr}_{\mathrm{x}} \mathrm{Ag}_{\mathrm{y}} \mathrm{MnO}_{3-\delta}$ perovskite single phase formed at $800^{\circ} \mathrm{C}$, and the solubility of $\mathrm{Ag}$ in the crystal lattice of the perovskite was up to 5 mol\%. The single-phase materials revealed thermal stability in different oxidizing atmospheres up to sintering temperature of the cathode at $1050^{\circ} \mathrm{C}$. The exsolution of the metallic Ag nanoparticles was performed at $350-600^{\circ} \mathrm{C}$ in reducing atmosphere. Scanning electron and scanning transmission electron microcopy revealed a good mechanical contact of the Ag nanoparticles to the surface of the perovskite after reducing conditions. The electrochemical tests of the materials showed a good electrocatalytic effect of nanosized Ag toward oxygen reduction reaction. The electrochemical performance of the cathodes revealed the dependence on electrolyte material and exsolution time.

(C) The Author(s) 2019. Published by ECS. This is an open access article distributed under the terms of the Creative Commons Attribution 4.0 License (CC BY, http://creativecommons.org/licenses/by/4.0/), which permits unrestricted reuse of the work in any medium, provided the original work is properly cited. [DOI: $10.1149 / 2.0361902 \mathrm{jes}]$

(cc) BY

Manuscript submitted November 15, 2018; revised manuscript received December 28, 2018. Published January 10, 2019. This was

Paper 1688 presented at the Cancun, Mexico, Meeting of the Society, September 30-October 4, 2018.

Solid oxide fuel cells (SOFCs) have attracted much attention as a potential alternative to conventional combustion-power plants for electrical power generation due to their high efficiency together with low emission and excellent fuel flexibility. ${ }^{1,2}$ Decreasing the operating temperature to the intermediate range $\left(500-800^{\circ} \mathrm{C}\right)$ is an important step toward the widespread commercialization of SOFCs technology, while the lack of stable cathode material with sufficiently high activity for oxygen reduction reaction (ORR) has become the main obstacle. ${ }^{3,4}$ Recently, much effort has emerged toward the development of alternative cathode materials with enhanced ORR activity at intermediate temperatures to compromise between cost, performance, and durability. ${ }^{3,4}$ An important direction in SOFC research is the development of high-performance cobalt-free perovskite oxides as alternative electrode materials for operation at intermediate temperatures. ${ }^{3,4}$ Iron-based perovskites have received particular attention because of high abundance, low cost, and favorable stability of iron oxide. ${ }^{5-9}$ Unfortunately, the electrocatalytic activity of most iron-based perovskite electrode materials for ORR is still not high enough at intermediate temperatures.

The formation of composite electrodes ${ }^{10,11}$ and the design of unique electrode architectures ${ }^{12-16}$ have widely emerged as alternative strategies for improving the electrode performance and stability. ${ }^{17}$ Infiltration has been the most applied technique for introducing the nanoparticles onto electrode surfaces. ${ }^{18-22}$ The modification of selected electrodes with some precious metals (Ag, Pd, and $\mathrm{Pt}),{ }^{23-26}$ or perovskite oxide-based nanoparticles, ${ }^{12-14}$ has been reported as significantly enhancing the catalytic activity of the electrodes toward ORR. Some potential drawbacks of the infiltration method may include non-uniform distribution of the as-prepared nanoparticles, reduced porosity of the electrode, and complicated processing procedures. ${ }^{27}$ Coarsening of nanoparticles at elevated temperatures is also a serious concern for most nanoparticle-modified electrodes. ${ }^{28}$ On the other hand, exsolution enables a novel approach to nanodesign the electrodes increasing the effective surface area and enhancing the catalytic activity of the materials for various electrochemical applications. ${ }^{17,23,29-36}$

Silver (Ag) is known to improve the oxygen exchange reaction activity. ${ }^{23} \mathrm{Ag}$-containing electrodes have shown high activity toward ORR making $\mathrm{Ag}$ as an efficient and promising component for SOFC cathodes. ${ }^{37-39}$ Attempts were made to either mix or impregnate SOFC cathodes (e.g. $\mathrm{La}_{\mathrm{x}} \mathrm{Sr}_{\mathrm{y}} \mathrm{MnO}_{3-\delta}, \mathrm{LSM}$ ) with Ag. ${ }^{40-42}$ Problems can arise during impregnation due to low adhesion forces between the Ag precursor solutions and the ceramic cathode material. ${ }^{27}$ On the other

\footnotetext{
*Electrochemical Society Member.
}

zE-mail: roksa@dtu.dk hand, mechanical mixing of metals and ceramics always comprise the ductility of the metal, what makes the particles rolled to irregular flat bands destroying the microstructure of the cathode. ${ }^{43}$ Attempts were made to apply $\mathrm{La}_{0.65} \mathrm{Sr}_{0.3} \mathrm{MnO}_{3-\delta}$ as a SOFC cathode materials synthesized by the Pechini method with small amounts of very finely and homogeneously distributed $\mathrm{Ag} .{ }^{40}$ The solubility of $\mathrm{Ag}$ in the $\mathrm{La}_{0.65} \mathrm{Sr}_{0.3} \mathrm{MnO}_{3-\delta}$ perovskite was lower than $1 \mathrm{wt} \%$, while higher amounts of Ag segregated as solid metal. The SOFC cathode produced a moderate current density due to the low sintering temperature to avoid melting of $\mathrm{Ag} .^{40}$ Recent study has shown that Ag-modified LSM can be introduced as a novel precursor for nanosized silver decorated LSM electrode under cathodic polarization with improved stability and in situ electrochemical regeneration capability with the electrochemical intercalation/de-intercalation of Ag metal, however not fully understood and sufficiently supported in the article. ${ }^{41}$ Application of exsoluted $\mathrm{Ag}$ has recently arisen as a novel heterostructured cathode based on $\mathrm{Sr}_{0.95} \mathrm{Ag}_{0.05} \mathrm{Nb}_{0.1} \mathrm{Co}_{0.9} \mathrm{O}_{3-\delta}$ (SANC) with the exsoluted $\mathrm{Ag}$ nanoparticles on an active perovskite backbone. ${ }^{23}$ The cathode had low ASR value $\left(\sim 0.214 \Omega \mathrm{cm}^{2}\right.$ at $\left.500^{\circ} \mathrm{C}\right)$ and the peak power density of $\sim 1.116 \mathrm{~W} \mathrm{~cm}^{-2}$ at $500^{\circ} \mathrm{C}$. Thus, the design concept may open up a brand new approach to the fabrication of stable and high performance cathodes for the SOFCs.

Here we report on an alternative method for the synthesis of Ag-doped $\mathrm{La}_{\mathrm{x}} \mathrm{Sr}_{\mathrm{y}} \mathrm{MnO}_{3-\delta}$-based materials (LSAM), which is suitable for producing $\mathrm{Ag}$-doped single phase LSM-based perovskite oxides. A very homogeneous distribution of Ag on the surface of A-site deficient perovskite was determined after ex situ performed exsolution in reducing atmosphere. The cathode materials were characterized by $\mathrm{X}$-ray powder diffraction (XRD), surface area [according to Brunauer, Emmett and Teller (BET)], temperature programmed reduction (TPR), scanning electron (SEM) and scanning transmission electron (STEM) microscopies. The influence of exsolution of $\mathrm{Ag}$ on the electrochemical performance of the cathode material was evaluated by symmetric cell tests on $8 \%$ yttria-stabilized zirconia (YSZ8) and $10 \%$ gadoliniadoped ceria (CGO10).

\section{Experimental}

Synthesis of the materials. - The ceramic cathode materials with the nominal composition $\mathrm{La}_{1-\mathrm{x}-\mathrm{y}} \mathrm{Sr}_{\mathrm{x}} \mathrm{Ag}_{\mathrm{y}} \mathrm{MnO}_{3-\delta}$ (LSAM), where $\mathrm{x}=$ 0.15 and $0.3 ; y=0-0.05$ were prepared by a modified citrate complexation method (modified Pechini method) and is summarized in Figure 1. The appropriate amount of EDTA was dissolved in diluted $\mathrm{NH}_{3}$ solution followed by the addition of $\mathrm{AgNO}_{3}$. The solution with $\mathrm{pH} \sim 12$ was mixed for a while and citric acid was added until completely dissolved. The amount ratio of total metal ions, EDTA 


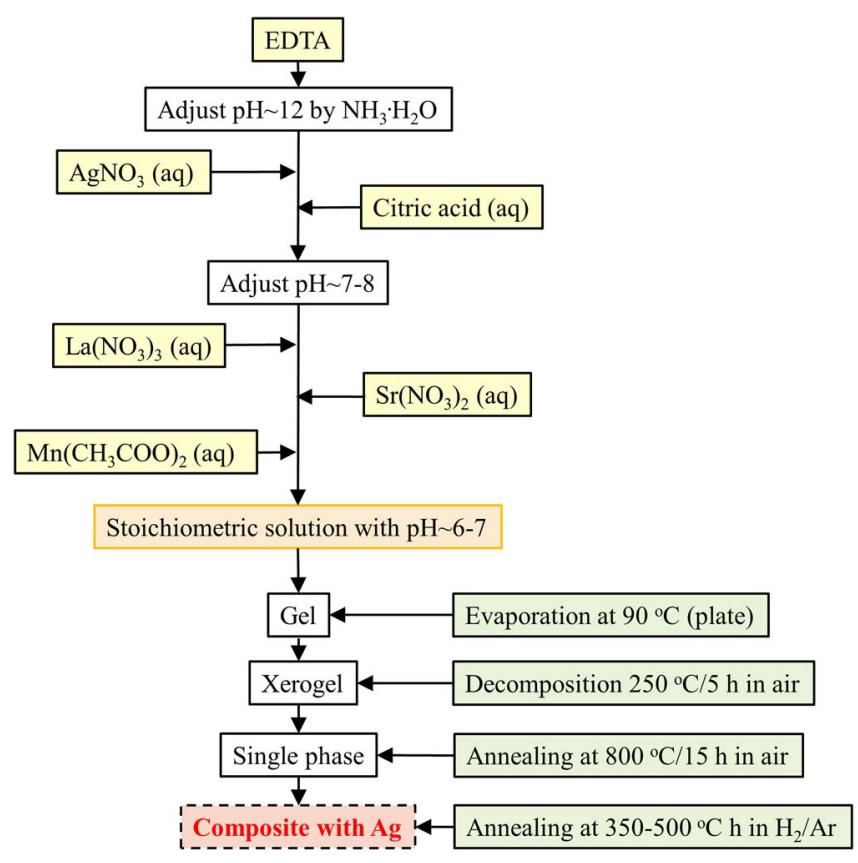

Figure 1. The schematic of the synthesis method for the LSAM materials. The ex situ exsolution conditions are included.

and citric acid was optimized to be $1: 2: 3$. The $\mathrm{pH}$ of the solution was adjusted to 7-8. $\quad \mathrm{La}\left(\mathrm{NO}_{3}\right)_{3} \cdot 6 \mathrm{H}_{2} \mathrm{O}, \quad \mathrm{Sr}\left(\mathrm{NO}_{3}\right)_{2} \quad$ and $\mathrm{Mn}\left(\mathrm{CH}_{3} \mathrm{COO}\right)_{2} \cdot 4 \mathrm{H}_{2} \mathrm{O}$ (Sigma Aldrich and Merck, Germany; quality: $>99.9 \%$ analytical pure) were dissolved separately in de-ionized water and slowly added to the main solution to avoid any precipitation. The solution was stirred at ambient temperature for 1 $\mathrm{h}$ with the following temperature increase to $90^{\circ} \mathrm{C}$ for the solvent to evaporate until the gelation started. The gel was precalcined at $250^{\circ} \mathrm{C}$ for $5 \mathrm{~h}$ and afterwards fired at $800^{\circ} \mathrm{C}$ for $15 \mathrm{~h}$ to combust all organic compounds, to decompose the nitrate ions and to obtain the main phase of the cathode materials. The residue was a fine dark black powder, which was further grinded on an agate mortar.

The pure $\mathrm{La}_{1-\mathrm{x}} \mathrm{Sr}_{\mathrm{x}} \mathrm{MnO}_{3-\delta}$ (LSM, $\mathrm{x}=0.15$ and 0.3 ) without $\mathrm{Ag}$ used as a reference were powders synthesized by the modified Pechini method.

The ex situ exsolution of $\mathrm{Ag}$ nanoparticles was performed in a tube furnace at $350-600^{\circ} \mathrm{C}$ for $2-15 \mathrm{~h}$ in a $50 \mathrm{ml} / \mathrm{min}$ flow of $5 \% \mathrm{H}_{2} / \mathrm{Ar}$.

Materials characterization.-Phase purity of the powders was confirmed by powder XRD using a Bruker D8 diffractometer (USA) with filtered $\mathrm{CuK}_{\alpha 1}$ irradiation at $40 \mathrm{kV}$ and $44 \mathrm{~mA}$. The diffraction patterns were collected at room temperature by step scanning in the range of $15 \leq 2 \theta \leq 90^{\circ}$ with a scan rate of $0.6-2^{\circ} \mathrm{min}^{-1}$. The sample was equilibrated for $5 \mathrm{~min}$ at each temperature. The Rietveld refinement was performed with Winpow software (DTU, Denmark) using an orthorhombic structure model Pbnm (No. 62) for the perovskite and a cubic structure model $\mathrm{Fm} \overline{3} \mathrm{~m}$ (No.221) for Ag. Initially, refinements were performed varying global parameters such as lattice parameters, peak shape parameters, background, phase fractions and sample displacement correction. Finally, fitting of the fractional occupancy and isotropic atomic displacement factors (ADFs) was also done. The surface area was determined by means of BET using Quantachrome iQ Autosorb Automated Gas Sorption System (USA). SEM imaging was carried out with TM3000 and Carl Zeiss Merlin field emission (Germany) scanning electron microscopes in secondary electron (SE) and back-scattered electron (BSE) modes. The InLens, HE-S2 and AsB detectors were used in the Zeiss Merlin electron microscope. Scanning transmission electron microscopy was performed with JEOL $3000 \mathrm{~F}$ microscope.
The oxygen nonstoichiometry and the average oxidation state of $\mathrm{Mn}$ in LSAM and LSM oxides were measured by iodometric titration. ${ }^{44}$ Approximately $30-35 \mathrm{mg}$ of sample was dissolved in a round-necked vessel in $\mathrm{HCl}$ solution. The residue of $\mathrm{AgCl}_{2}$ was filtered away, washed and weighed in order to determine the amount of $\mathrm{Ag}$ in the materials. An excess of potassium iodide (KI) and ca. $10-20 \mathrm{ml}$ distilled degassed water were added. Then the vessel was closed and slightly heated in order to fully dissolve the sample. Iodometric titration of the rest of the solution was performed using $0.01 \mathrm{M}$ thiosulfate $\left(\mathrm{S}_{2} \mathrm{O}_{3}{ }^{2-}\right)$ solution. Starch was used as an indicator.

The synthesized powders were further ball milled for $24 \mathrm{~h}$ in isopropanol and mixed with $10 \%$ gadolinia-doped ceria (CGO10) or $8 \%$ yttria-stabilized zirconia (YSZ8, Tosoh, Japan) in order to obtain the inks for electrochemical cells with LSAM-based cathodes. The dry powder mixture was combined with Disperbyk180 dispersant in dipropylene glycol (DPG). Further, the appropriate amounts of graphite and Santicizer 261 were added as a poreformer and a plasticizer, respectively. Poly(methyl methacrylate) (PMMA) was used as an additive and polyvinylpyrrolidone (PVPK90) was used as a binder. All the constituents were mixed with $\mathrm{ZrO}_{2}$ balls for $72 \mathrm{~h}$ to form a paste, which was then screen-printed on top of an $8 \mathrm{~mol} \%$ yttriastabilized zirconia (8YSZ) and 10\% gadolinia-doped ceria (CGO10) electrolytes of about $300 \mu \mathrm{m}$ in thickness. A 'functional layer' of $15-20 \mu \mathrm{m}$ in thickness consisting of a mixture of $60 \% 8 \mathrm{YSZ}$ or CGO10 and 40\% LSAM was deposited. The sintering of the electrodes was carried out at $1050^{\circ} \mathrm{C}$ for $2 \mathrm{~h}$ in air.

Electrochemical measurements.-The electrochemical cell tests were performed on $6 \times 6 \mathrm{~mm}^{2}$ symmetric cells with platinum coating as a current collector. The measurements were done in an alumina housing in $20 \% \mathrm{O}_{2} / \mathrm{Ar}$. The electrical contact was made by means of a fine gold mesh and the samples were mounted in a setup with gold meshes kept in contact with the cells with alumina bar load. Before mounting the samples, Pt-paste (Engelhard) was added on top of the cells and sintered in situ at $850^{\circ} \mathrm{C}$. The electrochemical impedance spectroscopy (EIS) was performed using a Gamry Reference 600 potensiostat/galvanostat impedance analyzer. The setup used for the measurements has been described elsewhere. ${ }^{45}$ The EIS was recorded on the samples as follows. The frequency window spanned was $1 \mathrm{MHz}$ to $0.05 \mathrm{~Hz}$. Six points were measured at each decade. An amplitude of $24 \mathrm{mV}$ was used throughout. The measurements were done at temperatures of $800,700,600^{\circ} \mathrm{C}$ and $500^{\circ} \mathrm{C}$ in the above order. The in situ exsolution was performed in $5 \% \mathrm{H}_{2} / \mathrm{Ar}$ before the measurements in $20 \% \mathrm{O}_{2} / \mathrm{Ar}$. All measurements were done on four identical symmetrical cells. The fitting of the data was done using the Elchemea Analytical (DTU Energy) ${ }^{46}$ with the circuit $R_{\mathrm{s}}\left(R_{1} Q_{1}\right)\left(R_{2} Q_{2}\right)\left(R_{3} Q_{3}\right)$, where $R$ is a resistance and $Q$ is a constant phase element with the admittance

$$
Y=Y_{0}\left(j \omega / \omega_{0}\right)^{n}
$$

where $Y_{0}$ and $n$ are found from the fitting. $\omega$ is the cyclic frequency. In the fitting, the $n$ values were at first allowed to vary freely. After fitting, all the data and the averages of the $n$ values were found. The data were then fitted again using the averages of the $n$ values using equations as follows ${ }^{47}$

$$
\begin{gathered}
C=R^{(1-n) / n} Y_{0}^{1 / n} \\
F_{\max }=\frac{1}{2 \pi}\left(R Y_{0}\right)^{-1 / n}
\end{gathered}
$$

\section{Results}

The procedure of the optimized wet chemical synthesis route for $\mathrm{La}_{1-\mathrm{x}-\mathrm{y}} \mathrm{Sr}_{\mathrm{x}} \mathrm{Ag}_{\mathrm{y}} \mathrm{MnO}_{3-\delta}$ (LSAM) and exsolution of $\mathrm{Ag}$ nanoparticles is shown in Fig. 1. Fig. 2 summarizes the XRD results of heat-treatment conditions of LSAM materials in air. The phase pure orthorhombic Ag-doped LSAM perovskite is obtained after firing at $800^{\circ} \mathrm{C}$ for 15 $\mathrm{h}$ in air. The lower the calcination temperature, the more amount of 


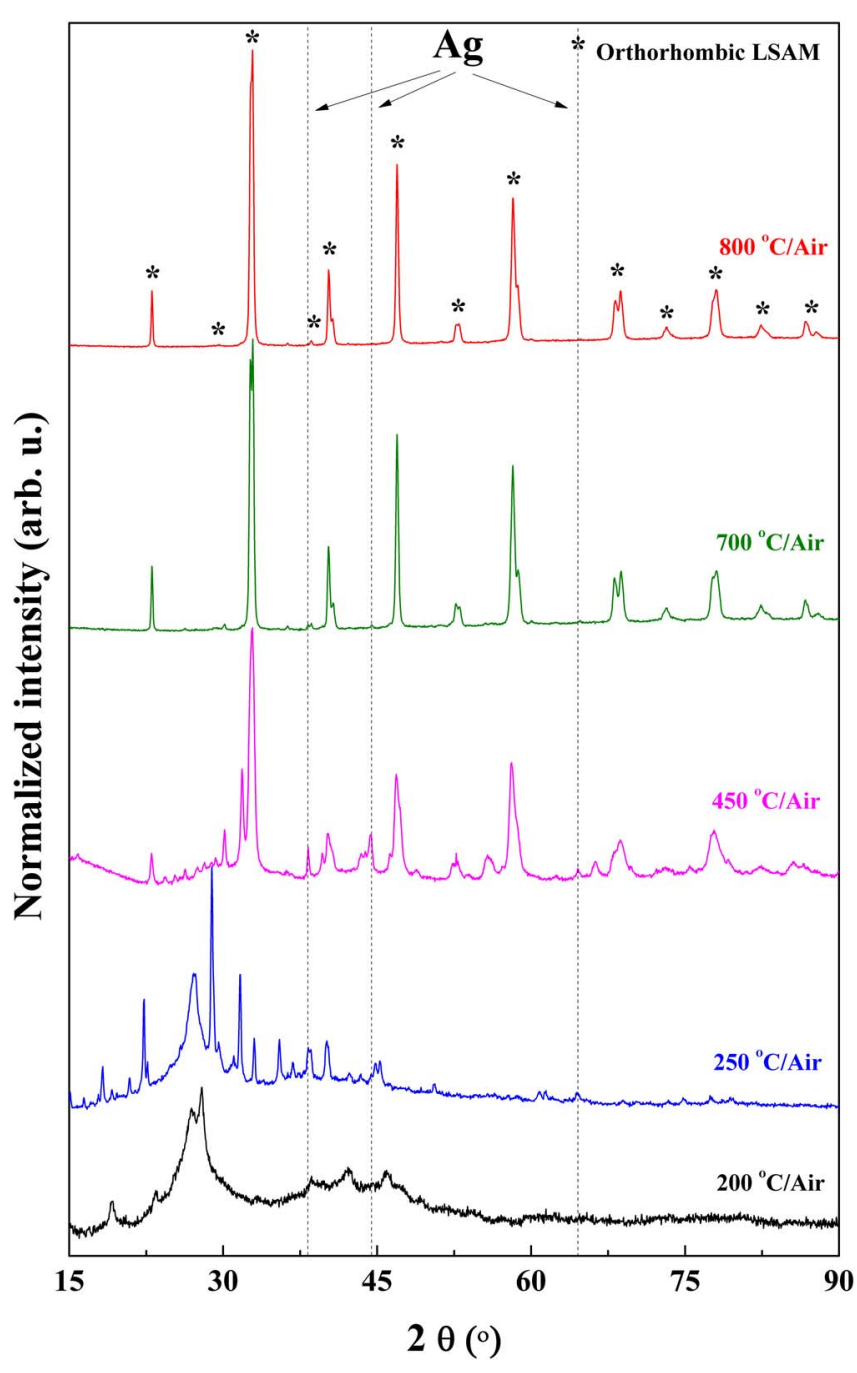

Figure 2. XRD results for the powders synthesized at different temperature for $15 \mathrm{~h}$ in air. The main peak positions of the cubic $\mathrm{Ag}$ phase are marked with the dashed lines.

metallic Ag is detected. The shift of peak positions of the orthorhombic LSAM phase are highlighted in Fig. 3. Upon increase of the Ag doping level in LSAM, the cell volume of the perovskite increase (Fig. 3 and Table II). The XRD results in Table II indicate that the exsolution process in reducing atmosphere induces expansion of the lattice according to the increase in cell parameters and cell volume, respectively. The lattice parameter of the cubic Ag structure was $\sim 4.08 \AA$. The weight percent of $\mathrm{Ag}$ in the composites are summarized in $\mathrm{Ta}-$ ble II showing close proximity of experimental values to the theoretical results.

The oxygen nonstoichiometry and the mean valence of Mn of the LSM15 (15 mol\% Sr), LSAM152 (15 mol\% Sr and $2 \mathrm{~mol} \% \mathrm{Ag}$ ) and LSAM155 (15 mol\% Sr and $5 \mathrm{~mol} \% \mathrm{Ag}$ ) powders were evaluated by iodometry (Table I). LSAM shows slightly higher average valences of

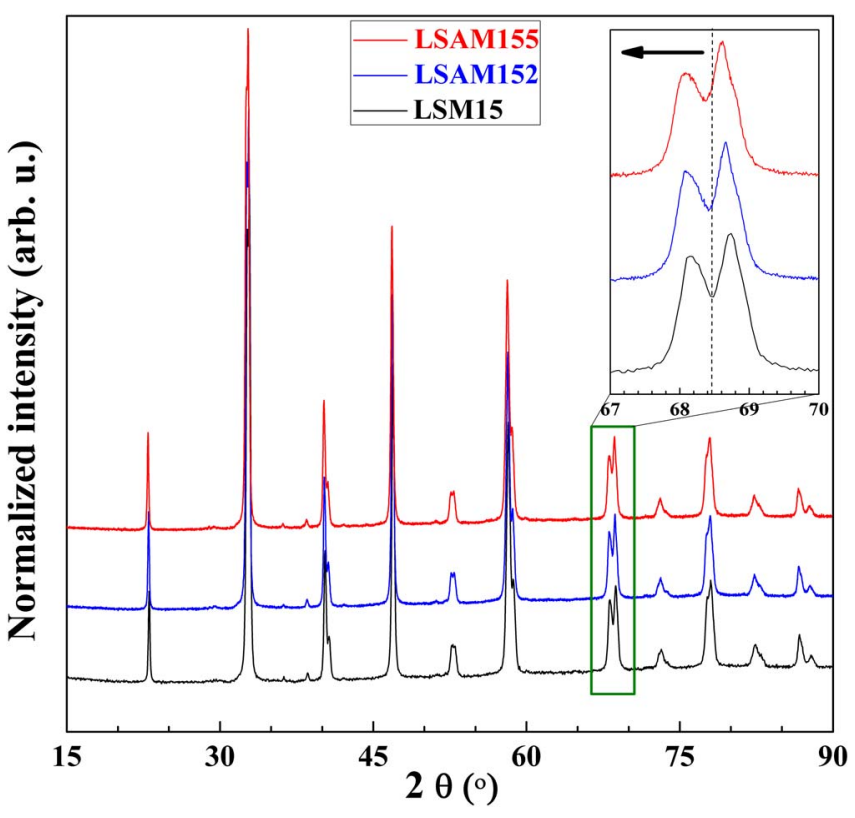

Figure 3. XRD of the single-phase LSAM materials without Ag (black), with $2 \mathrm{~mol} \%$ (blue) and $5 \mathrm{~mol} \%$ (red) of $\mathrm{Ag}$.

Mn ions and reduced oxygen vacancy concentration as compared with LSM15. The amount of $\mathrm{Mn}^{4+}$ increases with the increase of Ag doping level in LSAM. This supports doping of Ag into the A-site of the perovskite lattice as targeted. Table II shows the results of the structural XRD analysis and the BET surface area for the $\mathrm{La}_{1-\mathrm{x}-\mathrm{y}} \mathrm{Sr}_{\mathrm{x}} \mathrm{Ag}_{\mathrm{y}} \mathrm{MnO}_{3-\delta}$ cathode materials calcined at $800-1100^{\circ} \mathrm{C}$ including Ag-free LSM materials. The BET surface area was around $3 \mathrm{~m}^{2} / \mathrm{g}$ for all samples, which is larger than for the Ag-free powders $\left(2 \mathrm{~m}^{2} / \mathrm{g}\right)$, and the influence of $\mathrm{Ag}$ on the BET surface area can be seen. The difference in the BET surface area for the samples before and after exsolution can be determined.

Fig. 4 shows the XRD results for the exsolution of Ag nanoparticles from LSAM155 perovskite material. It can be seen that the main peaks of cubic Ag are visible after heat-treatment of LSAM materials at $450^{\circ} \mathrm{C}$ for $5 \mathrm{~h}$ in $5 \% \mathrm{H}_{2} / \mathrm{Ar}$. The exsolution conditions were investigated experimentally at $350-600^{\circ} \mathrm{C}$. The exsolution at $350^{\circ} \mathrm{C}$ is very slow and was chosen first to avoid decomposition of LSM phase which decomposes at $>550^{\circ} \mathrm{C}$ into different oxides. The reduction of the LSAM material induces the shift of the XRD peak positions to lower $2 \theta$ angles (Fig. 4).

The microstructure of LSAM155 before and after exsolution measured by SEM is shown in Fig. 5. The particle size of the materials after firing at $800^{\circ} \mathrm{C}$ for $15 \mathrm{~h}$ in air was found below $200 \mathrm{~nm}$ by linear intercept method (Fig. 5a). The particles are round-shaped. The microstructure of LSAM155ex material after exsolution of Ag nanoparticles is shown in Fig. 5b. Small Ag nanoparticles with different size are formed on the surface of the perovskite. Fig. $5 \mathrm{c}$ shows SEM micrograph in secondary electron mode (SE) with the Ag nanoparticles on the surface of the LSAM155ex perovskite. The roundshaped Ag nanoparticle size was determined below $20 \mathrm{~nm}$. The same part of the microstructure of LSAM155ex material is represented in

Table I. The results for iodometric titration of the $\mathrm{La}_{0.85-\mathrm{x}} \mathrm{Sr}_{0.15} \mathrm{Ag}_{\mathrm{x}} \mathrm{Mn}^{\sigma+} \mathrm{O}_{3-\delta}$ materials.

Parameters

\begin{tabular}{ccccrrrr}
\cline { 3 - 6 } Material & Synthesis temperature $\left({ }^{\circ} \mathrm{C}\right)$ & $\mathrm{x}$ (theor) & $\mathrm{x}$ (exper.) & $\delta$ & \multicolumn{2}{c}{$\mathrm{Mn}^{4+}(\%)$} \\
\hline LSM15 & 800 & 0 & - & 0.013 & 3.124 \\
LSAM152 & & 0.02 & 0.0192 & 0.0292 & 3.131 \\
LSAM155 & & 0.05 & 0.0489 & 0.0041 & 12.4
\end{tabular}


Table II. The results of powder sample characterization. Exsolution was performed at $350^{\circ} \mathrm{C}$ for $2 \mathrm{~h}$.

Cell parameters $(\AA)$

\begin{tabular}{|c|c|c|c|c|c|c|c|c|c|c|}
\hline \multirow[b]{2}{*}{ Material } & \multicolumn{5}{|c|}{ Perovskite (orthorhombic) } & \multicolumn{4}{|c|}{ Ag (cubic) } & \multirow[b]{2}{*}{$\begin{array}{l}\text { BET surface } \\
\text { area }\left(\mathrm{m}^{2} / \mathrm{g}\right)\end{array}$} \\
\hline & $\mathrm{a}$ & b & c & $\begin{array}{c}\text { Volume, } \\
\AA^{3}\end{array}$ & $\begin{array}{l}\text { Density, } \\
\mathrm{g} \cdot \mathrm{cm}^{-3}\end{array}$ & $\mathrm{a}$ & $\begin{array}{c}\text { Volume, } \\
\AA^{3}\end{array}$ & $\begin{array}{l}\text { Density, } \\
\mathrm{g} \cdot \mathrm{cm}^{-3}\end{array}$ & $\begin{array}{c}\text { Wt\%* } \\
\text { (Theo wt } \%)\end{array}$ & \\
\hline LSAM152 & $5.517 \pm 0.001$ & $5.461 \pm 0.001$ & $7.754 \pm 0.002$ & $233.63 \pm 0.09$ & 6.638 & - & - & - & - & 3.112 \\
\hline LSAM152ex & $5.543 \pm 0.001$ & $5.508 \pm 0.001$ & $7.830 \pm 0.001$ & $239.06 \pm 0.08$ & 6.487 & $3.975 \pm 0.001$ & $62.82 \pm 0.04$ & 11.40 & $0.9(0.9)$ & 3.155 \\
\hline LSAM155 & $5.517 \pm 0.001$ & $5.464 \pm 0.001$ & $7.753 \pm 0.001$ & $233.75 \pm 0.05$ & 6.608 & - & - & - & - & 2.933 \\
\hline LSAM155ex & $5.531 \pm 0.001$ & $5.508 \pm 0.001$ & $7.852 \pm 0.002$ & $239.24 \pm 0.06$ & 6.307 & $4.077 \pm 0.001$ & $67.77 \pm 0.03$ & 10.57 & $1.5(2.3)$ & 3.326 \\
\hline LSM15 & $5.516 \pm 0.001$ & $5.459 \pm 0.001$ & $7.747 \pm 0.002$ & $233.28 \pm 0.09$ & 6.666 & - & - & - & - & 2.014 \\
\hline LSM30 & $5.503 \pm 0.001$ & $5.436 \pm 0.001$ & $7.716 \pm 0.002$ & $230.83 \pm 0.06$ & 6.726 & - & - & - & - & 2.077 \\
\hline
\end{tabular}

back-scattered electron mode (BSE) in Fig. 5d. The differences in the microstructure of the LSAM155ex perovskite and Ag metal nanoparticles can be observed. The microstructure of LSAM152 containing less $\mathrm{Ag}(2 \mathrm{~mol} \%)$ is shown in Fig. 5e. Smaller amount of Ag in the LSAM materials results in smaller concentration of exsoluted Ag nanoparticles on the surface of the cathode. Fig. 5f shows STEM image of Ag nanoparticles and Fig. 5g EDS mapping results from STEM. The distinct nanosized Ag-rich regions can be seen on the surface of the materials.

The temperature dependence of the impedance data is illustrated in Fig. 6. The area specific resistance (ASR) is seen to decrease with increasing temperature. Fig. 7 gives an example of an impedance spectrum of a symmetrical cell, together with the results of the fitting. The data presented in Fig. 8 were recorded on a symmetrical cell in $20 \% \mathrm{O}_{2} / \mathrm{Ar}$ at $600^{\circ} \mathrm{C}$. It can be seen that the spectrum consists of three arcs (Figs. 7 and 8). In general, all the results from the EIS measurements at different temperatures could be fitted with an equivalent circuit with three $(R Q)$ elements in series, together with a series resistance $R_{\mathrm{s}}$. The results of the fitting, in terms of $R$ values of the individual arcs, are given in Tables III together with $F_{\max }$ and $C_{\omega}$. The variation in the data is based on measurements and fittings on four symmetrical cells. It is seen that all the arcs are temperature and exsolution time dependent. The exsolution time dependence is largest for the medium and low frequency arcs (Fig. 8). The $n$ values vary between $0.5-0.85$ for the high frequency arc, $0.68-0.85$ for the medium frequency arc, and $0.38-0.53$ for the low frequency arc. The near-equivalent capacities for all three arcs are smallest for the cells after $12 \mathrm{~h}$ of exsolution. The summit frequencies of the three arcs all

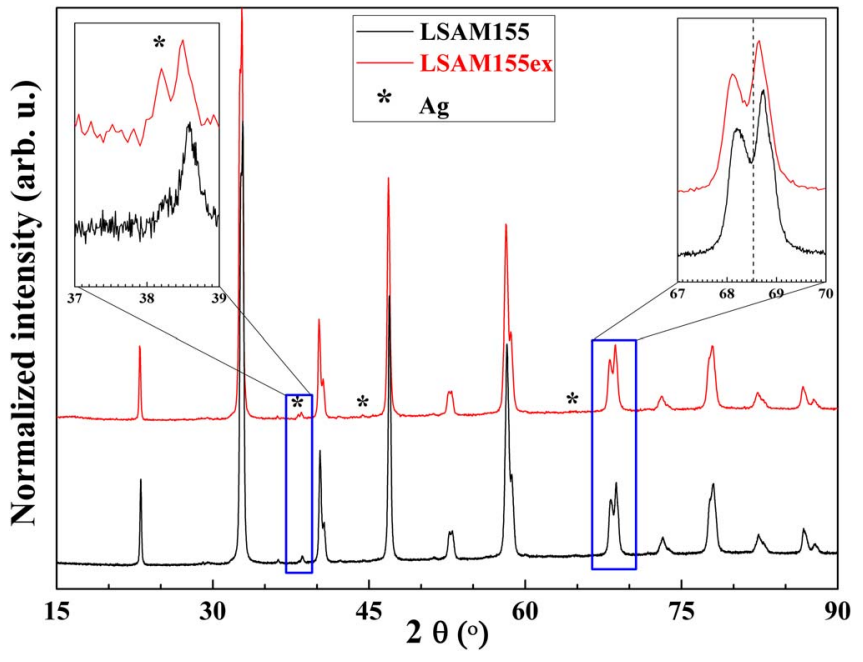

Figure 4. XRD results for the LSAM155 material before (black) and after (red) exsolution of the $\mathrm{Ag}$ nanoparticles at $350^{\circ} \mathrm{C}$ for $2 \mathrm{~h}$ in the flow of $5 \%$ $\mathrm{H}_{2} / \mathrm{Ar}$. depend on the exsolution time. The summit frequencies for the high frequency arc are largest for the cells before exsolution. The summit frequencies for the medium frequency arc are almost unaffected by exsolution time. The summit frequencies for the low frequency arc are largest for the cells before exsolution, and the effect is considerable.

The Arrhenius plots for the total ASR with CGO and YSZ electrolytes are given in Fig. 9. The total ASR decreases with increasing temperature and exsolution time. The activation energies for the two types of cells and individual arcs are given in Tables IV and V, respectively. The slightly scattered activation energies do not show a clear dependence on the type of the electrolyte and on the exsolution time. The activation energies are almost constant with increasing exsolution time. The series resistance also depends on the CGO or YSZ electrolyte, however not on exsolution time. In a pure CGO electrolyte, the series resistance is around $1.3 \Omega \mathrm{cm}^{2}$ at $600^{\circ} \mathrm{C}$, whereas it is around $2.2 \Omega \mathrm{cm}^{2}$ at $600^{\circ} \mathrm{C}$ when $\mathrm{YSZ}$ electrolyte is present.

\section{Discussion}

The performance of the electrodes, as reflected by the ASR values, is the best for LSAM/CGO composite cathodes with CGO electrolyte.

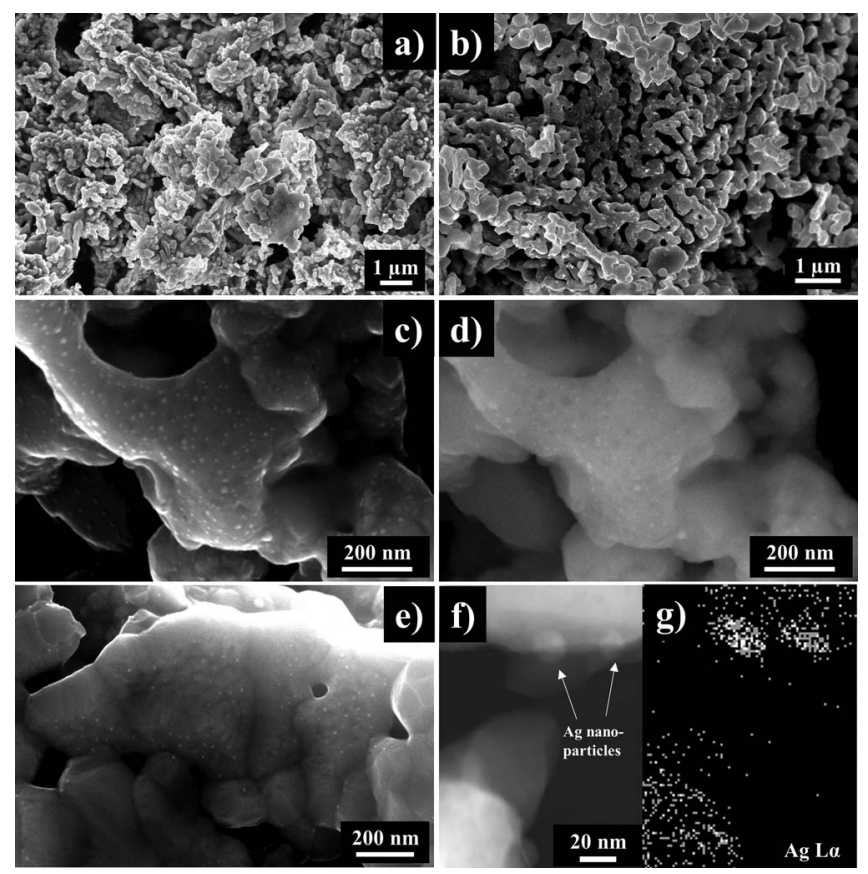

Figure 5. The images of the microstructure of (a) LSAM155 as-synthesized powder; (b) after heat-treatment at $450^{\circ} \mathrm{C}$ for $2 \mathrm{~h}$ in $5 \% \mathrm{H}_{2} / \mathrm{Ar}$; (c) LSAM155 with Ag nanoparticles after exsolution in SE mode and (d) BSE mode; (e) SEM image of LSAM152 after exsolution; (f) STEM image of LSAM155 and (g) STEM EDS mapping results of Ag nanoparticles. 
Table III. The $R, C_{\omega}$, and $F$ max values of the individual arcs for symmetrical cells with a CGO and YSZ electrolytes in $20 \% \mathrm{O}_{2}$ in Ar. $R$ is given in $\Omega \mathrm{cm}^{2}, C_{\omega}$ is in $\mu \mathrm{F} \mathrm{cm}^{-2}$, and $F \max$ is in $\mathrm{Hz}$.

\begin{tabular}{|c|c|c|c|c|c|c|c|c|c|c|}
\hline \multirow[b]{2}{*}{$\mathrm{T},{ }^{\circ} \mathrm{C}$} & \multirow[b]{2}{*}{ Exs. time } & \multicolumn{3}{|c|}{ High frequency } & \multicolumn{3}{|c|}{ Medium frequency } & \multicolumn{3}{|c|}{ Low frequency } \\
\hline & & $\mathrm{R}_{1}, \Omega \mathrm{cm}^{2}$ & $\mathrm{C}_{1}, \mu \mathrm{F} \mathrm{cm}^{-2}$ & $\mathrm{~F}_{1}, \mathrm{~Hz}$ & $\mathrm{R}_{2}, \Omega \mathrm{cm}^{2}$ & $\mathrm{C}_{2}, \mu \mathrm{F} \mathrm{cm}^{-2}$ & $\mathrm{~F}_{2}, \mathrm{~Hz}$ & $\mathrm{R}_{3}, \Omega \mathrm{cm}^{2}$ & $\mathrm{C}_{3}, \mu \mathrm{F} \mathrm{cm}^{-2}$ & $\mathrm{~F}_{3}, \mathrm{~Hz}$ \\
\hline & & & & & CGO & & & & & \\
\hline 500 & Before & $0.60 \pm 0.01$ & 0.05 & 1.96 & $23.70 \pm 0.07$ & 0.60 & 253 & $26.46 \pm 0.08$ & 21.20 & 0.4 \\
\hline 600 & & $0.28 \pm 0.06$ & 0.02 & 5.38 & $2.95 \pm 0.05$ & 0.14 & 608 & $1.83 \pm 0.11$ & 2.61 & 53.2 \\
\hline 700 & & $0.09 \pm 0.08$ & 15.60 & 3060 & $0.22 \pm 0.07$ & 0.16 & 2280 & $0.46 \pm 0.19$ & 16.90 & 38.3 \\
\hline 800 & & $0.06 \pm 0.02$ & 11.20 & 245000 & $\begin{array}{r}0.04 \pm 0.04 \\
\text { YSZ }\end{array}$ & 0.24 & 22300 & $0.08 \pm 0.21$ & 916 & 392 \\
\hline 500 & Before & $5.47 \pm 0.02$ & 0.02 & 2160 & $51.56 \pm 0.01$ & 5.12 & 1.5 & $41.79 \pm 0.08$ & 276 & 0.3 \\
\hline 600 & & $1.04 \pm 0.04$ & 0.04 & 11700 & $6.01 \pm 0.02$ & 4.38 & 23.3 & $7.33 \pm 0.07$ & 137 & 3.8 \\
\hline 700 & & $0.25 \pm 0.10$ & 0.10 & 48200 & $1.11 \pm 0.09$ & 2.38 & 226 & $1.97 \pm 0.03$ & 68.00 & 27.1 \\
\hline 800 & & $0.04 \pm 0.05$ & 0.78 & 184000 & $\begin{array}{r}0.06 \pm 0.03 \\
\text { CGO }\end{array}$ & 0.66 & 22200 & $0.28 \pm 0.11$ & 28.80 & 399 \\
\hline 500 & $3 \mathrm{~h}$ & $0.57 \pm 0.06$ & 9.22 & 317 & $21.44 \pm 0.10$ & 0.28 & 2 & $24.42 \pm 0.05$ & 223 & 0.4 \\
\hline 600 & & $0.27 \pm 0.07$ & 13.90 & 781 & $2.81 \pm 0.11$ & 0.15 & 6.4 & $1.84 \pm 0.02$ & 2.38 & 50.3 \\
\hline 700 & & $0.24 \pm 0.03$ & 0.01 & 2780 & $0.20 \pm 0.15$ & 0.13 & 3740 & $0.41 \pm 0.13$ & 142 & 62 \\
\hline 800 & & $0.06 \pm 0.05$ & 0.05 & 272000 & $\begin{array}{r}0.04 \pm 0.03 \\
\text { YSZ }\end{array}$ & 0.62 & 22200 & $0.08 \pm 0.17$ & 78.30 & 455 \\
\hline 500 & $3 \mathrm{~h}$ & $5.55 \pm 0.11$ & 0.02 & 2080 & $45.40 \pm 0.03$ & 5.10 & 1.9 & $39.2 \pm 0.05$ & 242 & 0.42 \\
\hline 600 & & $1.02 \pm 0.12$ & 0.04 & 12100 & $5.22 \pm 0.09$ & 2.81 & 7.8 & $7.08 \pm 0.04$ & 124 & 4.4 \\
\hline 700 & & $0.24 \pm 0.09$ & 0.11 & 51100 & $0.90 \pm 0.15$ & 1.94 & 3310 & $1.916 \pm 0.12$ & 63.30 & 29.5 \\
\hline 800 & & $0.04 \pm 0.08$ & 0.77 & 187000 & $\begin{array}{r}0.04 \pm 0.17 \\
\text { CGO }\end{array}$ & 0.51 & 50300 & $0.25 \pm 0.18$ & 27.20 & 478 \\
\hline 500 & $6 \mathrm{~h}$ & $0.34 \pm 0.08$ & 0.0408 & 326 & $18.12 \pm 0.12$ & 0.48 & 3.6 & $21.06 \pm 0.03$ & 167 & 0.6 \\
\hline 600 & & $0.28 \pm 0.07$ & 0.645 & 458 & $2.66 \pm 0.25$ & 0.10 & 8.3 & $1.83 \pm 0.16$ & 1.22 & 91.1 \\
\hline 700 & & $0.26 \pm 0.10$ & 13.8 & 5030 & $0.20 \pm 0.13$ & 0.14 & 3950 & $0.41 \pm 0.11$ & 1.44 & 50.3 \\
\hline 800 & & $0.08 \pm 0.02$ & 80.4 & 239000 & $\begin{array}{c}0.04 \pm 0 \\
\text { YSZ }\end{array}$ & 0.23 & 29600 & $0.06 \pm 0.17$ & 9.70 & 2700 \\
\hline 500 & $6 \mathrm{~h}$ & $5.80 \pm 0.06$ & 0.02 & 2120 & $36.12 \pm 0.09$ & 210 & 0.5 & $43.89 \pm 0.12$ & 4.79 & 2.2 \\
\hline 600 & & $1.02 \pm 0.07$ & 0.04 & 13000 & $4.58 \pm 0.17$ & 3.44 & 40.4 & $6.90 \pm 0.03$ & 98.50 & 5.6 \\
\hline 700 & & $0.25 \pm 0.02$ & 0.10 & 52800 & $0.80 \pm 0.11$ & 1.68 & 448 & $1.90 \pm 0.07$ & 57.20 & 33.5 \\
\hline 800 & & $0.04 \pm 0.13$ & 0.77 & 185000 & $\begin{array}{r}0.03 \pm 0.10 \\
\text { CGO }\end{array}$ & 4.57 & 75800 & $0.24 \pm 0.07$ & 25.20 & 542 \\
\hline 500 & $12 \mathrm{~h}$ & $0.30 \pm 0.08$ & 0.04 & 402 & $17.03 \pm 0.08$ & 0.45 & 4.3 & $20.45 \pm 0.11$ & 146 & 0.7 \\
\hline 600 & & $0.42 \pm 0.07$ & 0.01 & 2420 & $2.20 \pm 0.07$ & 92.10 & 10.8 & $1.42 \pm 0.24$ & 1.93 & 111 \\
\hline 700 & & $0.25 \pm 0.05$ & 11.90 & 12300 & $0.19 \pm 0.16$ & 0.14 & 4880 & $0.39 \pm 0.26$ & 118 & 63.3 \\
\hline 800 & & $0.04 \pm 0.08$ & 3.05 & 234000 & $\begin{array}{r}0.03 \pm 0.11 \\
\text { YSZ }\end{array}$ & 0.04 & 140000 & $0.07 \pm 0.13$ & 41.80 & 841 \\
\hline 500 & $12 \mathrm{~h}$ & $5.75 \pm 0.07$ & 0.02 & 2150 & $30.66 \pm 0.06$ & 179 & 0.7 & $38.71 \pm 0.21$ & 4.61 & 2.8 \\
\hline 600 & & $0.96 \pm 0.03$ & 0.04 & 14900 & $4.06 \pm 0.07$ & 3.35 & 49.8 & $6.56 \pm 0.08$ & 98.10 & 6 \\
\hline 700 & & $0.24 \pm 0.08$ & 0.11 & 54700 & $0.60 \pm 0.03$ & 1.36 & 739 & $1.83 \pm 0.03$ & 54.30 & 36.5 \\
\hline 800 & & $0.04 \pm 0.04$ & 0.78 & 189000 & $0.02 \pm 0.12$ & 4.05 & 115000 & $0.21 \pm 0.13$ & 24.10 & 674 \\
\hline
\end{tabular}

A screen printed symmetrical cell containing Ag-decorated LSAM reveals improved electrochemical performance of the electrode after exsolution. The exsoluted Ag nanoparticles have enhanced activity of the electrodes, which is improving with exsolution time what could be attributed to the concentration of exsoluted $\mathrm{Ag}$ nanoparticles. On the other hand, the effect in general can be explained by Fig. 10. When the electrode material is subjected to reducing atmosphere $\left(\mathrm{H}_{2}\right)$, the exsolution of $\mathrm{Ag}$ nanoparticles occurs. If the electrode material is a mixed ionic electronic conductor, almost all the exsoluted Ag nanoparticles are efficient toward ORR (Fig. 10, I) and the effect on the electrochemical performance of the electrodes would be considerable. If the cathode material is only electronic conductor, not all the exsoluted Ag nanoparticles would be efficient toward ORR (Fig. 10, II), and only those on triple phase boundaries (TPBs) between electrode, electrolyte and gas phases. Consequently, the effect on electrochemical performance will be gentle. All these processes are very dependent on LSAM and electrolyte composite processing, since LSAM is a good electronic conductor and composites with the electrolyte material increase ionic conductivity of the cathode and the length of TPBs. Including the fact that all the arcs in EIS (Table III) are dependent on the exsolution of Ag nanoparticles and exsolution time, it could be indicated that most of the processes occur close to the electrode- electrolyte-gas interface. The performance of the cells with YSZ is worse due to less contact points between the LSM/YSZ/Ag cathode and the YSZ electrolyte compared to the probable amount of contact points between the LSM/CGO/Ag cathodes and the CGO electrolyte. The conductivity of the electrolyte material plays an important role.

As can be seen in Figs. 8 and 9 and Table III, the magnitude of all three arcs is decreased when $\mathrm{Ag}$ is exsoluted from the single phase LSAM and is dependent on the exsolution time. The low frequency arc is the one that decreases the most and according to the literature is normally attributed to a slow redox oxygen-exchange reaction at the surface of the electrode (Eq. 4). ${ }^{45,47,48}$

$$
\mathrm{O}_{\text {ads }}+2 \mathrm{e}^{-}+\mathrm{v}_{\mathrm{O}}^{\bullet \bullet} \rightarrow \mathrm{O}_{\mathrm{O}}^{\mathrm{x}}
$$

where $\mathrm{O}_{\text {ads }}$ is adsorbed oxygen species, $\mathrm{e}^{-}$is an electron, $\mathrm{v}_{O}^{\bullet \bullet}$ is an oxygen vacancy and $\mathrm{O}_{\mathrm{O}}^{\mathrm{x}}$ is oxygen on the oxygen site. This arc is minimized due to a larger surface area of the cathode with small metal nanoparticles formed as a result of the exsolution in LSAM and good catalytic properties of Ag, see Fig. 5. It could be expected two scenarios enhancing the electrochemical performance of the cells. ${ }^{49}$ If the surface reaction represented by the low frequency arc in EIS would be diffusion controlled or due to the roughness, there would be no changes in the activation energy before and after exsolution, 


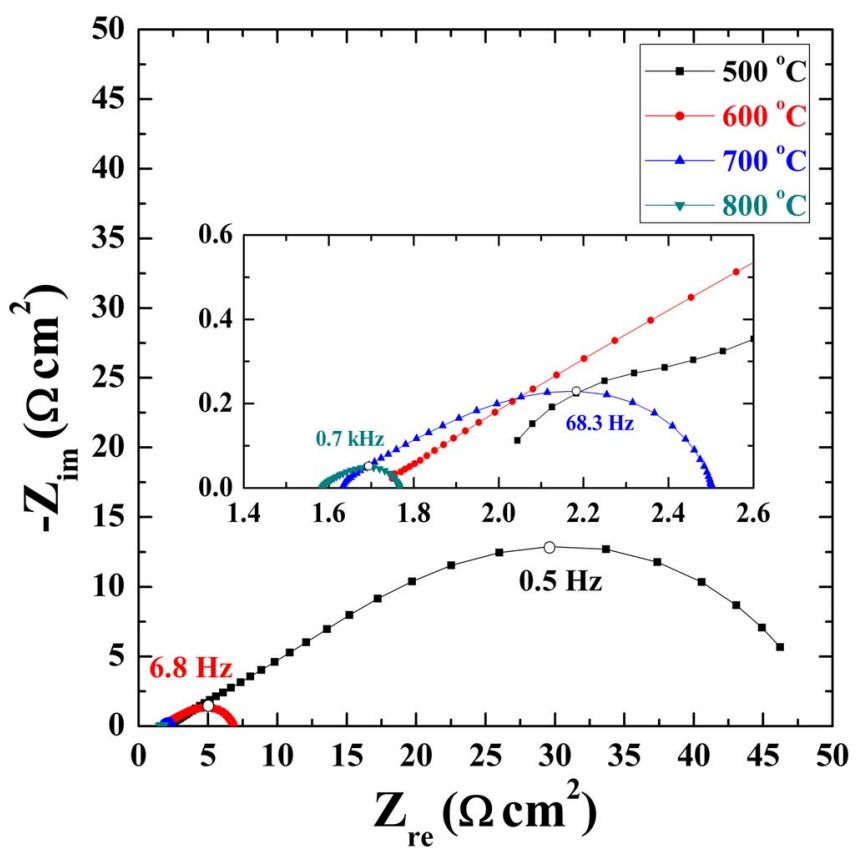

Figure 6. Electrochemical impedance spectra of a symmetrical cell with LSAM/CGO electrode recorded at $500,600,700$, and $800^{\circ} \mathrm{C}$ in $20 \% \mathrm{O}_{2}$ in Ar. The solid lines are fitted data; dots are measured data.

but only a change in ASR. ${ }^{49}$ However, this is not the case in the current work represented by Table $\mathrm{V}$ as $R_{3}$. It can be seen that the activation energy changes before and after exsolution what implicates that it is a change in mechanism, and the performance of the electrodes is surface reaction enhanced by the catalytic activity of Ag nanoparticles. The different changes in the activation energies before and after exsolution observed for CGO and YSZ could be explained by ionic conductivity differences first. The YSZ material has a slight decrease in the activation energy after exsolution what could be due to lower ionic conductivity of YSZ in the composite and a fast surface exchange reaction. The process is not surface but diffusion limited. However, in the case of CGO an increase in activation energy can be seen which can be attributed to the thermal activation of the surface limited reaction. ${ }^{49}$

The low frequency arc is dependent on the electrolyte material and is smaller when the CGO electrolyte is present. The partial pressures of oxygen $\left(\mathrm{pO}_{2}\right)$ dependence of this arc is around $1 / 4,{ }^{47}$ as predicted for a charge-transfer Reaction $4 .^{50}$ The calculated nearequivalent capacitance of this arc is also in the range predicted for a chemical capacitance. ${ }^{48}$ The exsolution and its time affect the medium

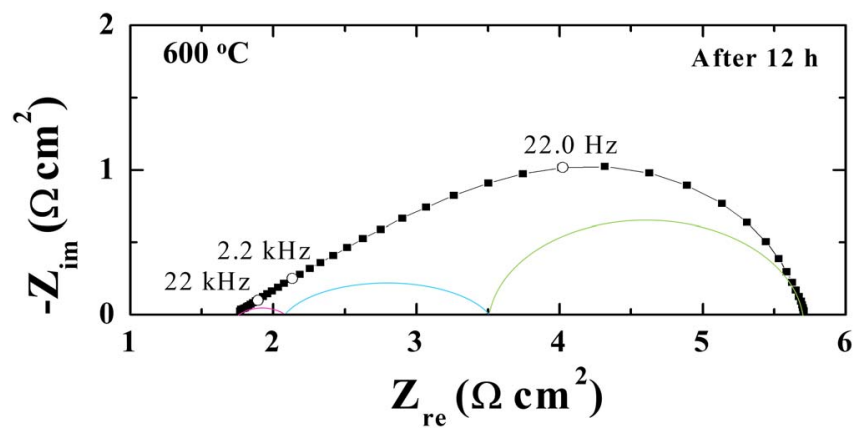

Figure 7. EIS spectrum of a symmetrical cell (porous LSAM/CGO/dense $\mathrm{CGO} /$ porous LSAM/CGO) in $20 \% \mathrm{O}_{2}$ in $\mathrm{Ar}$ at $600^{\circ} \mathrm{C}$, i.e., the response is from two electrodes in series with the electrolyte resistance. The colored lines are deconvolution of the data; the solid black line is the full fit.
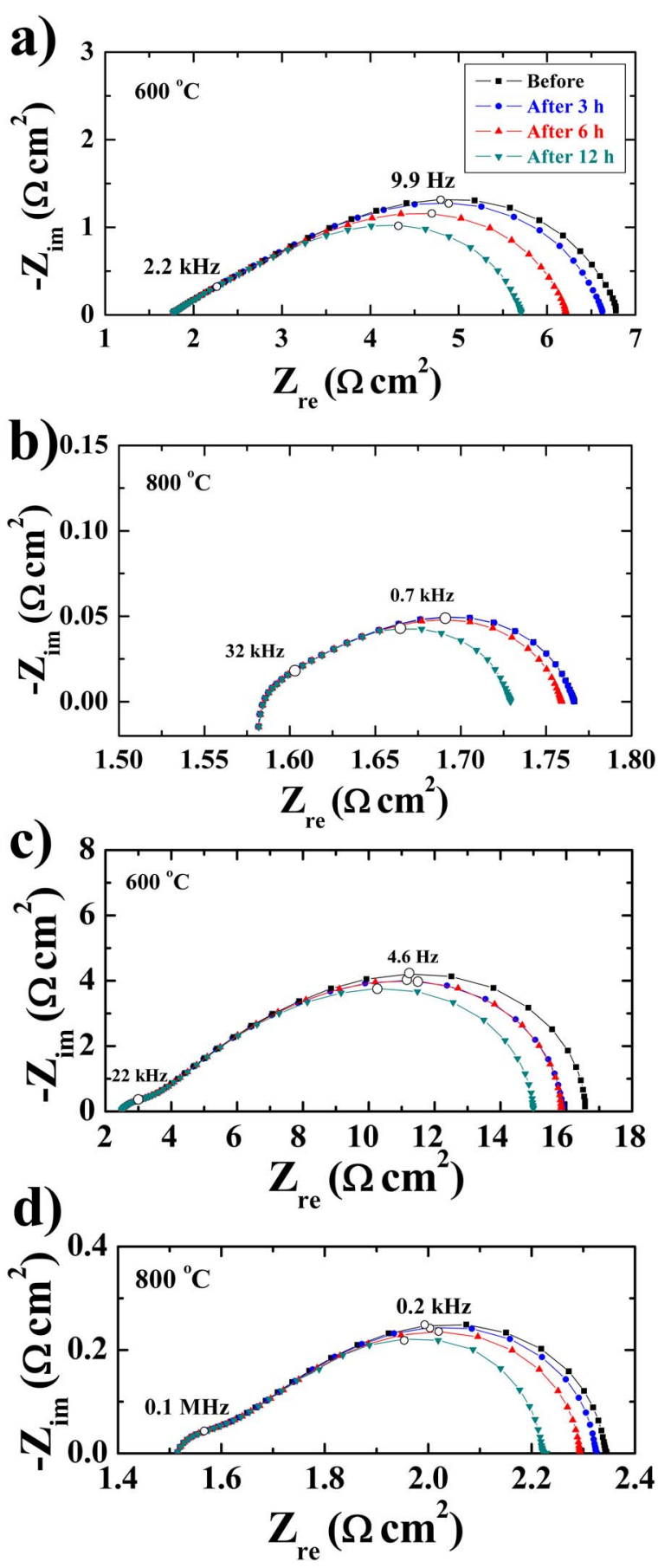

Figure 8. EIS spectra of a symmetrical cell with a (a)-(b) CGO and (c)-(d) YSZ recorded at 600 and $800^{\circ} \mathrm{C}$ in $20 \% \mathrm{O}_{2}$ in $\mathrm{Ar}$ after $0-12 \mathrm{~h}$ of in situ exsolution in $5 \% \mathrm{H}_{2}$ in Ar. The solid lines are fitted data; dots are measured data.

frequency arc. According to literature, this arc could be a diffusion of oxide anions through the bulk or the surface of the electrode. ${ }^{45,47,51}$ It could be speculated that if surface diffusion is the case, the medium frequency arc would depend on the presence of a metal nanoparticles when the process occurs close to the electrode-electrolyte interface. The $p \mathrm{O}_{2}$ dependence of this arc is around $1 / 4 .^{47}$ The high frequency arc (see Fig. 6), referring to the literature, is known to be due to transport and transfer of oxide ions or oxygen intermediates across the LSAM cathode and electrolyte interface and through the electrolyte material of the composite. ${ }^{45,47,48,51}$ The exsolution of Ag nanoparticles from the perovskite slightly affects the high frequency arc, and 

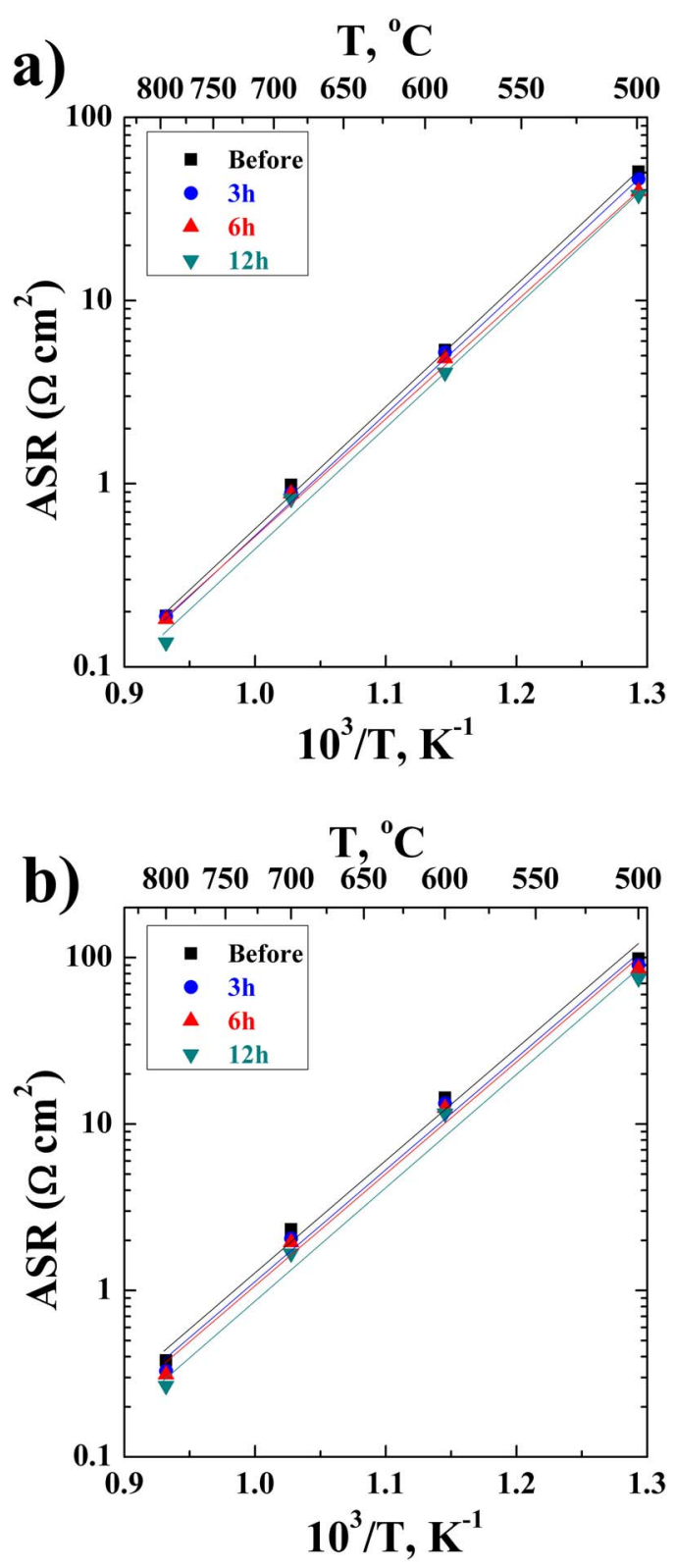

Figure 9. Arrhenius plots of the total ASR as a function of temperature and in situ exsolution time in 5\% $\mathrm{H}_{2}$ in Ar for the cells with a (a) CGO and (b) YSZ electrolyte. The total ASR decreases with increasing exsolution time.

the near-equivalent capacity calculated using Eq. 2 is around 0.1$5 \mu \mathrm{F} / \mathrm{cm}^{2}$ implying a double layer capacitance. ${ }^{47,48,52}$ The magnitude of this arc is much larger for the cells with YSZ electrolyte than for the cells with CGO meaning that the better conductivity of CGO electrolyte improves the electrode-electrolyte exchange reaction. The near-equivalent capacity is higher for the cells with CGO electrolyte, what according to the literature, indicates that there are more contact points between the composite cathode and the electrolyte. ${ }^{47}$ The $p \mathrm{O}_{2}$ dependence of the high frequency arc is small, approximately $1 / 16^{47}$ indicating that the process involves oxide anions and not oxygen. It is noteworthy that the absolute ASR values of the LSM/CGO cathodes are lower compared to the LSM/YSZ cathodes (Fig. 9) implicating that the backbone material is important in order to achieve highly active electrodes and showing that the exsoluted Ag from LSAM enhances the slow oxygen-exchange reaction at the surface of the electrode. The catalytic properties of the exsoluted Ag from LSAM are maintained even when the screen-printed electrodes are heated to $800^{\circ} \mathrm{C}$, revealing that no coarsening of the exsoluted $\mathrm{Ag}$ nanoparticles is occurring.
From Tables IV and V it can be seen that the apparent activation energy is almost unaffected by the exsolution time what suggests that the mechanism of ORR is not much affected by the exsolution of the Ag nanoparticles, however the rate of ORR is changed.

In general, the doping of LSM with Ag can be described as follows in Reaction 5,

$$
2 \mathrm{La}_{\mathrm{La}}^{\mathrm{x}}+3 \mathrm{O}_{\mathrm{O}}^{\mathrm{x}} \stackrel{\mathrm{Ag}}{\rightarrow} \mathrm{Ag}_{\mathrm{La}}^{/ /}+\mathrm{v}_{\mathrm{O}}^{\bullet \bullet}+\mathrm{La}_{2} \mathrm{O}_{3}
$$

This reaction is supplemented by the Reaction 6 ,

$$
2 \mathrm{La}_{\mathrm{La}}^{\mathrm{x}}+3 \mathrm{O}_{\mathrm{O}}^{\mathrm{x}}+2 \mathrm{Mn}_{\mathrm{Mn}}^{\mathrm{x}} \stackrel{\mathrm{Ag}}{\rightarrow} \mathrm{Ag}_{\mathrm{La}}^{/ /}+2 \mathrm{Mn}_{\mathrm{Mn}}^{\bullet}+\mathrm{La}_{2} \mathrm{O}_{3}
$$

At low temperature oxidized $\mathrm{Ag}$ is stable in the perovskite lattice due to $\mathrm{Ag}_{2} \mathrm{O}$ in this lattice. The decomposition of $\mathrm{Ag}_{2} \mathrm{O}$ will depend on $p \mathrm{O}_{2}$ at different temperatures, and $\mathrm{Ag}_{2} \mathrm{O}$ would decompose at slightly higher than $200^{\circ} \mathrm{C}$ temperature in 0.2 atm $p \mathrm{O}_{2}$. Further, the materials are subjected to reducing atmosphere from room temperature where oxidized $\mathrm{Ag}$ is in the perovskite lattice. The exsolution of metallic $\mathrm{Ag}$ in reducing atmosphere is performed at elevated temperature due to kinetics and would be possible at room temperature in prolonged time. It is assumed that on cooling from the operation or exsolution temperature, part of $\mathrm{Ag}$ would be in the form of $\mathrm{Ag}_{2} \mathrm{O}$. However, ordinary XRD measurements did not reveal $\mathrm{Ag}_{2} \mathrm{O}$ but instead metallic Ag (Figs. 2-4). The synthesis is started by complexing oxidized $\mathrm{Ag}$ into carbon and oxygen based materials, correspondingly increasing the stability of oxidized Ag. However, the sol-gel chemistry of Ag-based materials is quite challenging to interpret.

The XRD, thermal analysis and iodometric titration results imply that introduction of the oxygen vacancies and the concentration of $\mathrm{Mn}^{4+}$ induce distortion of the orthorhombic phase and slight contraction of the lattice volume at low $\mathrm{pO}_{2}$. However, $\mathrm{Ag}^{+}$is considerably bigger than $\mathrm{La}^{3+}$ and induces overall lattice expansion. The A-site doping of LSM perovskite and exsolution of the Ag nanoparticles out from the crystal structure would induce more changes of the oxidation state for Mn together with slight reduction of the lattice. The defect equilibria of the exsolution could look as follows

$$
\begin{gathered}
\mathrm{Ag}_{\mathrm{Ag}}^{\mathrm{x}}+\mathrm{Mn}_{\mathrm{Mn}}^{\mathrm{x}} \rightarrow \mathrm{v}_{\mathrm{Ag}}^{\prime}+\mathrm{Mn}_{\mathrm{Mn}}^{\bullet}+\mathrm{Ag}_{\text {exs }}^{\mathrm{x}}(\mathrm{s}) \\
\mathrm{Ag}_{\mathrm{Ag}}^{\mathrm{x}}+\mathrm{O}_{\mathrm{O}}^{\mathrm{x}} \rightarrow 2 \mathrm{v}_{\mathrm{Ag}}^{\prime}+\mathrm{v}_{\mathrm{O}}^{\bullet \bullet}+1 / 2 \mathrm{O}_{2}(\mathrm{~g})+\mathrm{Ag}_{\text {exs }}^{\mathrm{x}}(\mathrm{s})
\end{gathered}
$$

According to the XRD results in Table II and Figs. 3 and 4, the exsolution process in reducing atmosphere induces slight expansion of the lattice what can be seen in the increase in cell parameters and cell volume. These results can be attributed only to the dominated reduction of $\mathrm{Mn}^{4+}$ to $\mathrm{Mn}^{3+}$ and $\mathrm{Mn}^{3+}$ to $\mathrm{Mn}^{2+}$. Referring to Fig. 4, which shows the XRD results for the exsolution of Ag nanoparticles from LSAM155 perovskite, one can conclude that the cubic Ag forms after heat-treatment of LSAM materials at $350^{\circ} \mathrm{C}$ for $2 \mathrm{~h}$ in $\mathrm{H}_{2} / \mathrm{Ar}$. However, the exsolution process is rather slow (Figs. 8 and 9) and the detection of exsoluted Ag nanoparticles is difficult by regular XRD due to very small size of the particles. One must be aware on choosing the exsolution conditions. The constant lattice parameter of the cubic Ag structure indicates that there is no strain effect between the perovskite and nanosized $\mathrm{Ag}$ particles. The weight percent of $\mathrm{Ag}$ in the composites summarized in Table II show very good agreement and close proximity of experimental values to the theoretical results. The BET surface area was around $3 \mathrm{~m}^{2} / \mathrm{g}$ for the pristine samples, which is larger than Ag-free LSM powders (Table II). The difference in the BET surface area for the samples before and after exsolution imply that the exsolution increases the total surface area of the materials and therefore the length of the TPBs so necessary for the ORR. The BET measurements were performed on the powder samples at specific conditions (see Table II). It would be expected that increasing the exsolution time as for the electrochemical cells investigated in this work, larger differences in the BET surface area would be determined. The TGA results implicate that the phase pure LSAM perovskite is stable up to $1100^{\circ} \mathrm{C}$ in air (results not shown) what enables sintering of LSAM materials at high temperature in order to get good attachment 
Table IV. Activation energies (eV) of the two types of cells in $20 \% \mathrm{O}_{2}$ in $\mathrm{Ar}$ before and after exsolution in $5 \% \mathrm{H}_{2}$ in $\mathrm{Ar}$.

Exsolution time

\begin{tabular}{cccrr}
\cline { 2 - 4 } Electrolyte & $0 \mathrm{~h}$ & $3 \mathrm{~h}$ & $6 \mathrm{~h}$ & $12 \mathrm{~h}$ \\
\hline CGO & $1.32 \pm 0.03$ & $1.31 \pm 0.02$ & $1.27 \pm 0.03$ & $1.32 \pm 0.06$ \\
YSZ & $1.32 \pm 0.08$ & $1.33 \pm 0.08$ & $1.33 \pm 0.08$
\end{tabular}

Table V. Activation energies (eV) of different arcs for the two types of cells in $20 \% \mathrm{O}_{2}$ in Ar before and after in situ exsolution in $5 \%$ H in $\mathrm{Ar}$.

Exsolution time

\begin{tabular}{|c|c|c|c|c|c|}
\hline \multirow[b]{2}{*}{ Electrolyte } & \multirow[b]{2}{*}{$\mathrm{R}$} & & & & \\
\hline & & $0 \mathrm{~h}$ & $3 \mathrm{~h}$ & $6 \mathrm{~h}$ & $12 \mathrm{~h}$ \\
\hline \multirow[t]{3}{*}{ CGO } & $\mathrm{R}_{1}$ & $1.28 \pm 0.16$ & $1.28 \pm 0.14$ & $1.30 \pm 0.14$ & $1.29 \pm 0.22$ \\
\hline & $\mathrm{R}_{2}$ & $1.55 \pm 0.10$ & $1.53 \pm 0.11$ & $1.49 \pm 0.11$ & $1.53 \pm 0.10$ \\
\hline & $\mathrm{R}_{3}$ & $1.17 \pm 0.09$ & $1.32 \pm 0.06$ & $1.37 \pm 0.08$ & $1.32 \pm 0.09$ \\
\hline \multirow[t]{3}{*}{ YSZ } & $\mathrm{R}_{1}$ & $1.17 \pm 0.12$ & $1.17 \pm 0.11$ & $1.17 \pm 0.09$ & $1.17 \pm 0.10$ \\
\hline & $\mathrm{R}_{2}$ & $1.55 \pm 0.21$ & $1.61 \pm 0.23$ & $1.62 \pm 0.26$ & $1.68 \pm 0.28$ \\
\hline & $\mathrm{R}_{3}$ & $1.28 \pm 0.04$ & $1.16 \pm 0.13$ & $1.20 \pm 0.12$ & $1.20 \pm 0.14$ \\
\hline
\end{tabular}

to the electrolyte. LSAM155 loses almost $5 \mathrm{wt} \%$ below $1100^{\circ} \mathrm{C}$ in general and $\sim 2.5 \mathrm{wt} \%$ at $800-1100^{\circ} \mathrm{C}$ what is in a good agreement with the theoretical amount of Ag by weight (Table II). This loss of 2.5 wt $\%$ could be attributed to the evaporation of $\mathrm{Ag}$ at high temperatures $\left(>\mathrm{T}_{\text {mp }}(\mathrm{Ag})=961^{\circ} \mathrm{C}\right)$.

With respect to the XRD patterns (Figs. 2-4) it can be concluded that all the materials crystallized in a perovskite structure irrespective of the addition of $\mathrm{Ag}$ or exsolution. The successful optimized wet chemical synthesis route for LSAM and exsolution of Ag nanoparticles is shown in Fig. 1. The method is called modified Pechini method because instead of ethylene glycol we used EDTA as both complexing and polycondensation agent. Fig. 2 summarizes the heat-treatment conditions of LSAM materials in air. The phase pure orthorhombic LSAM perovskite is obtained after firing at $800^{\circ} \mathrm{C}$ for $15 \mathrm{~h}$ in air. The shifts of the peak positions and thus descent variations in the lattice parameters due to incorporation of $\mathrm{Ag}$ as $\mathrm{Ag}^{+}$ions on the A-site position of $\mathrm{ABO}_{3}$ perovskite lattice could be detected. The increasing doping level of Ag slightly increases the cell parameters and cell volume of the materials (see Fig. 3 and Table II). This is in a good agreement with the doping of $\mathrm{LaMnO}_{3}$ perovskite by small amounts of $\mathrm{Sr}^{53}$ According to Shannon, the size of six-coordinated $\mathrm{Ag}^{+}$and $\mathrm{Sr}^{2+}$ is similar ${ }^{54}$ and this induces the expansion of the $\mathrm{LaMnO}_{3}$ perovskite lattice. It is noteworthy that $\mathrm{Ag}$ did not form any compounds

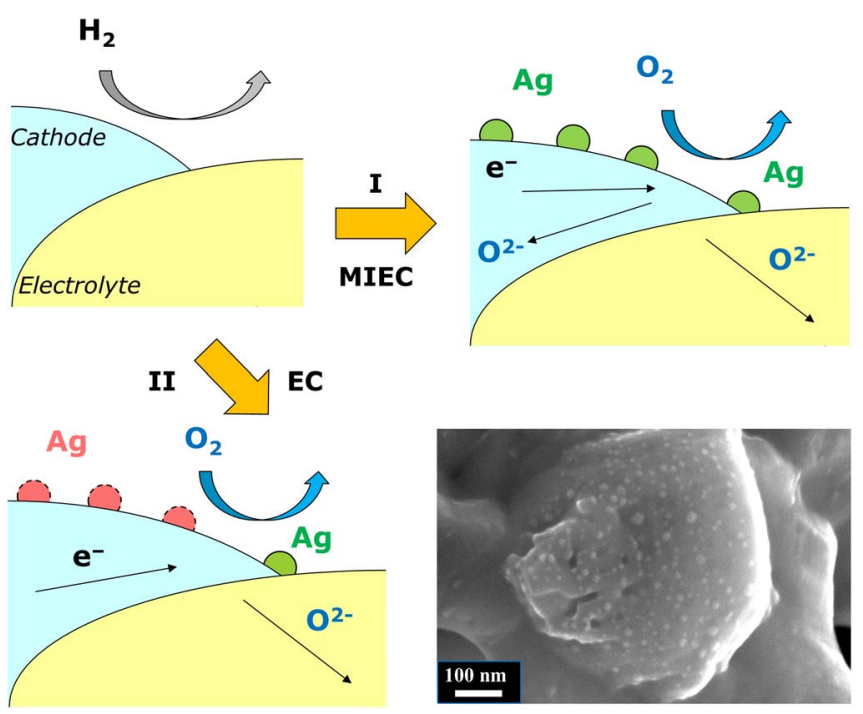

Figure 10. Possible mechanisms of exsoluted Ag nanoparticles toward ORR. as secondary phases, and only metallic Ag was detected in all the XRD patterns after exsolution of LSAM materials. The most important aspects of this procedure are the $\mathrm{pH}$ of each step, temperature, time of mixing and the ratio between the overall amount of cations, EDTA and citric acid. The materials in separate solutions were added dropwise in such a way that no precipitation was observed at all. The $\mathrm{AgNO}_{3}$ is added in the very beginning due to the intended complexation with $\mathrm{NH}_{3}$ and possible stabilization of $\mathrm{Ag}^{+}$in the aqueous solution. The gelation of the mixture is slow and has to be performed on the hot plate as much as possible in order to avoid extensive degassing in the furnace. The increase in the temperature must be slow especially up to $600^{\circ} \mathrm{C}$, where all the organic materials are decomposed. The method proposed in this work introduces the way to dope LSM-based materials with Ag up to $5 \mathrm{~mol} \%$ (2.3 wt $\%)$ in contrary to the authors from Ref. 40 who stated impossibility to Ag-dope LSM more than 1 wt $\%$. On the other hand, attempts to reproduce the procedure given in Ref. 41 was unsuccessful, since the results, methodology and support on the phase purity of the materials in the manuscript were scarce.

The SEM and STEM micrographs of the microstructure of LSAM155 before and after exsolution are shown in Fig. 5. The particle size of the materials after firing at $800^{\circ} \mathrm{C}$ for $15 \mathrm{~h}$ in air was below $200 \mathrm{~nm}$ (see Fig. 5a) by linear intercept method and the particles were round-shaped. The microstructure of LSAM155ex material after exsolution of Ag nanoparticles (Fig. 5b) suggests that small and stable Ag nanoparticles are formed with good adhesion on the surface of the perovskite. This is an advantage of the exsolution compared to impregnation. When compared SEM micrographs in secondary electron mode (SE) (Fig. 5c) and back-scattered electron mode (BSE) (Fig. $5 \mathrm{~d})$, the round-shaped Ag nanoparticles on the surface of the LSAM perovskite were determined and the size of Ag was below $20 \mathrm{~nm}$. The differences in the microstructure of the LSAM155ex perovskite and Ag metal nanoparticles can be observed which are confirmed by STEM EDS analysis (Figs. 5f-5g). It is important to note that the amount of exsoluted Ag nanoparticles on the surface of LSAM perovskites was proportional to the Ag doping level (see Fig. 5). Attempts were made to observe the discrete exsoluted Ag nanoparticles by transmission electron microscopy (TEM). However, the Ag nanoparticles were difficult to distinguish in terms of mass thickness contrast due to similar density with the LSM. Also, high-resolution TEM images were mainly dominated by lattice fringes from the LSM.

\section{Conclusions}

$\mathrm{La}_{1-\mathrm{x}-\mathrm{y}} \mathrm{Sr}_{\mathrm{x}} \mathrm{Ag}_{\mathrm{y}} \mathrm{MnO}_{3-\delta}(\mathrm{LSAM}, \mathrm{y}=0-0.05)$ were synthesized by the modified Pechini method. The materials were applied in composites with $\mathrm{CGO}$ and $\mathrm{YSZ}$ as symmetric cells at $500-800^{\circ} \mathrm{C}$ for the electrochemical oxygen reduction reaction. The solubility of $\mathrm{Ag}$ in 
the $\mathrm{La}_{1-\mathrm{x}-\mathrm{y}} \mathrm{Sr}_{\mathrm{x}} \mathrm{Ag}_{\mathrm{y}} \mathrm{MnO}_{3-\delta}$ perovskite reveled to be up to $5 \mathrm{~mol} \%$ with the good stability of the single phase materials in air and argon. The increased doping of the perovskite oxide induced expansion of the lattice volume. SEM images and XRD measurements showed the formation of around $20 \mathrm{~nm}$ very finely and homogeneously distributed $\mathrm{Ag}$ nanoparticles on the LSAM surface after a reductive heat-treatment at $350-600^{\circ} \mathrm{C}$ in $5 \% \mathrm{H}_{2} / \mathrm{Ar}$, with the $\mathrm{Ag}$ nanoparticle concentration influenced by the reduction temperature and Ag-doping level in LSM. The specific surface area of the materials increased after exsolution, and the lattice expansion was observed. LSAM was used as a cathode for SOFC, and exhibited lower ASR than other previously reported LSM-based cathodes. Exsolution of Ag nanoparticles was found to be a slow process and the electrochemical performance improved with increasing exsolution time. Our results indicate that Ag-nanodecorated LSAM/CGO10 and LSAM/YSZ8 composites may be efficient SOFC cathode materials for the oxygen reduction reaction.

\section{Acknowledgments}

The author Rokas Sažinas (RS) acknowledge financial support from Villum Foundation for the research activities performed at DTU Energy. RS would also like to acknowledge DTU Energy technicians and employees Jens Quitzau Adolphsen, Ebtisam Abdellahi, Annelise Mikkelsen, Ole Hansen, Lene Knudsen, Carsten Gynther Sørensen for the qualified technical support during the experiments.

\section{ORCID}

Rokas Sažinas (1D https://orcid.org/0000-0002-4422-890X

Kent Kammer Hansen (iD https://orcid.org/0000-0002-1349-958X

\section{References}

1. A. B. Stambouli and E. Traversa, "Solid oxide fuel cells (SOFCs): a review of an environmentally clean and efficient source of energy" Renew. Sust. Ener. Rev, 6, 433 (2002).

2. M. Dokiya, "SOFC system and technology" Solid State Ionics, 152-153, 383 (2002).

3. J. A. Kilner and M. Burriel, "Materials for Intermediate-Temperature Solid-Oxide Fuel Cells" Ann. Rev. Materi. Res., 44, 365 (2014).

4. A. Tarancón, M. Burriel, J. Santiso, S. J. Skinner, and J. A. Kilner, "Advances in layered oxide cathodes for intermediate temperature solid oxide fuel cells" J. Mater Chem., 20, 3799 (2010).

5. Y. Chen, W. Zhou, D. Ding, M. Liu, F. Ciucci, M. Tade, and Z. Shao, "Advances in Cathode Materials for Solid Oxide Fuel Cells: Complex Oxides without Alkaline Earth Metal Elements" Advanced Energy Materials, 5, 1500537 (2015).

6. J.-W. Yin, Y.-M. Yin, J. Lu, C. Zhang, N. Q. Minh, and Z.-F. Ma, "Structure and Properties of Novel Cobalt-Free Oxides $\mathrm{Nd}_{\mathrm{x}} \mathrm{Sr}_{1-\mathrm{x}} \mathrm{Fe}_{0.8} \mathrm{Cu}_{0.2} \mathrm{O}_{3-\delta}(0.3 \leq \mathrm{x} \leq 0.7)$ as Cathodes of Intermediate Temperature Solid Oxide Fuel Cells" J. Phys. Chem. C 118, 13357 (2014).

7. F. Dong, D. Chen, Y. Chen, Q. Zhao, and Z. Shao, "La-doped $\mathrm{BaFeO}_{3-\delta}$ perovskite as a cobalt-free oxygen reduction electrode for solid oxide fuel cells with oxygen-ion conducting electrolyte" J. Mater. Chem., 22, 15071 (2012).

8. F. Dong, Y. Chen, D. Chen, and Z. Shao, "Surprisingly high activity for oxygen reduction reaction of selected oxides lacking long oxygen-ion diffusion paths at intermediate temperatures: a case study of cobalt-free $\mathrm{BaFeO}$ (3-delta)" ACS Appl. Mater. Interfaces, 6, 11180 (2014).

9. G. Yang, C. Su, Y. Chen, F. Dong, M. O. Tade, and Z. Shao, "Cobalt-free $\mathrm{SrFe}_{0.9} \mathrm{Ti}_{0.1} \mathrm{O}_{3-\delta}$ as a high-performance electrode material for oxygen reduction reaction on doped ceria electrolyte with favorable $\mathrm{CO}_{2}$ tolerance" J. Eur. Ceram. Soc., 35, 2531 (2015).

10. K. T. Lee, A. A. Lidie, H. S. Yoon, and E. D. Wachsman, "Rational design of lowertemperature solid oxide fuel cell cathodes via nanotailoring of co-assembled composite structures" Angew. Chem. Int. Ed. Eng., 53, 13463 (2014).

11. E. P. Murray, T. Tsai, and S. A. Barnett, "Oxygen transfer processes in ( $\mathrm{La}, \mathrm{Sr}) \mathrm{MnO}_{3} / \mathrm{Y}_{2} \mathrm{O}_{3}$-stabilized $\mathrm{ZrO}_{2}$ cathodes: an impedance spectroscopy study" Solid State Ionics, 110, 235 (1998).

12. D. Ding, M. Liu, Z. Liu, X. Li, K. Blinn, X. Zhu, and M. Liu, "Efficient ElectroCatalysts for Enhancing Surface Activity and Stability of SOFC Cathodes" Advanced Energy Materials, 3, 1149 (2013).

13. X. Zhang, L. Liu, Z. Zhao, B. Tu, D. Ou, D. Cui, X. Wei, X. Chen, and M. Cheng, "Enhanced oxygen reduction activity and solid oxide fuel cell performance with a nanoparticles-loaded cathode" Nano Lett., 15, 1703 (2015).

14. W. Zhou, L. Ge, Z.-G. Chen, F. Liang, H.-Y. Xu, J. Motuzas, A. Julbe, and Z. Zhu, "Amorphous Iron Oxide Decorated 3D Heterostructured Electrode for Highly Efficient Oxygen Reduction" Chem. Mater, 23, 4193 (2011).
15. J. An, Y. B. Kim, J. Park, T. M. Gur, and F. B. Prinz, "Three-dimensional nanostructured bilayer solid oxide fuel cell with $1.3 \mathrm{~W} / \mathrm{cm}^{2}$ at $450^{\circ} \mathrm{C}$ " Nano Lett., 13, 4551 (2013).

16. D. Lee, Y.-L. Lee, A. Grimaud, W. T. Hong, M. D. Biegalski, D. Morgan, and Y. Shao-Horn, "Enhanced Oxygen Surface Exchange Kinetics and Stability on Epitaxial $\mathrm{La}_{0.8} \mathrm{Sr}_{0.2} \mathrm{CoO}_{3-\delta}$ Thin Films by $\mathrm{La}_{0.8} \mathrm{Sr}_{0.2} \mathrm{MnO}_{3-\delta}$ Decoration" J. Phys. Chem. $C, 118,14326$ (2014).

17. J. T. S. Irvine, D. Neagu, M. C. Verbraeken, C. Chatzichristodoulou, C. Graves, and M. B. Mogensen, "Evolution of the electrochemical interface in high-temperature fuel cells and electrolysers" Nature Energy, 1, 15014 (2016).

18. S. P. Jiang, "A review of wet impregnation-An alternative method for the fabrication of high performance and nano-structured electrodes of solid oxide fuel cells" Materials Science and Engineering: A, 418, 199 (2006).

19. J. M. Vohs and R. J. Gorte, "High-Performance SOFC Cathodes Prepared by Infiltration" Advanced Materials, 21, 943 (2009)

20. S. P. Jiang, "Nanoscale and nano-structured electrodes of solid oxide fuel cells by infiltration: Advances and challenges" Int. J. Hydrogen Energy, 37, 449 (2012).

21. D. Ding, X. Li, S. Y. Lai, K. Gerdes, and M. Liu, "Enhancing SOFC cathode performance by surface modification through infiltration" Energy \& Environmental Science, 7, 552 (2014)

22. Z. Jiang, C. Xia, and F. Chen, "Nano-structured composite cathodes for intermediatetemperature solid oxide fuel cells via an infiltration/impregnation technique" Electrochimica Acta, 55, 3595 (2010).

23. Y. Zhu, W. Zhou, R. Ran, Y. Chen, Z. Shao, and M. Liu, "Promotion of Oxygen Reduction by Exsolved Silver Nanoparticles on a Perovskite Scaffold for Low-Temperature Solid Oxide Fuel Cells" Nano Lett., 16, 512 (2016)

24. M. Sahibzada, S. J. Benson, R. A. Rudkin, and J. A. Kilner, "Pd-promoted $\mathrm{La}_{0.6} \mathrm{Sr}_{0.4} \mathrm{Co}_{0.2} \mathrm{Fe}_{0.8} \mathrm{O}_{3}$ cathodes" Solid State Ionics, 113, 285 (1998)

25. K. Sasaki, J. Tamura, H. Hosoda, T. N. Lan, K. Yasumoto, and M. Dokiya, "Ptperovskite cermet cathode for reduced-temperature SOFCs" Solid State Ionics, 148, 551 (2002).

26. S. Guo, H. Wu, F. Puleo, and L. Liotta, "B-Site Metal (Pd, Pt, Ag, Cu, Zn, Ni) Promoted $\mathrm{La}_{1-\mathrm{x}} \mathrm{Sr}_{\mathrm{x}} \mathrm{Co}_{1-\mathrm{y}} \mathrm{Fe}_{\mathrm{y}} \mathrm{O}_{3-\delta}$ Perovskite Oxides as Cathodes for IT-SOFCs" Catalysts, 5, 366 (2015).

27. X. Lou, Z. Liu, S. Wang, Y. Xiu, C. P. Wong, and M. Liu, "Controlling the morphology and uniformity of a catalyst-infiltrated cathode for solid oxide fuel cells by tuning wetting property" J. Pow. Sour, 195, 419 (2010).

28. Y. Gong, D. Palacio, X. Song, R. L. Patel, X. Liang, X. Zhao, J. B. Goodenough, and K. Huang, "Stabilizing nanostructured solid oxide fuel cell cathode with atomic layer deposition" Nano Lett., 13, 4340 (2013).

29. B. Hua, M. Li, Y. F. Sun, J. H. Li, and J. L. Luo, "Enhancing Perovskite Electrocatalysis of Solid Oxide Cells Through Controlled Exsolution of Nanoparticles" ChemSusChem, 10, 3333 (2017).

30. K. Huang, "An emerging platform for electrocatalysis: perovskite exsolution" Science Bulletin, 61, 1783 (2016)

31. O. Kwon, S. Sengodan, K. Kim, G. Kim, H. Y. Jeong, J. Shin, Y. W. Ju, J. W. Han, and G. Kim, "Exsolution trends and co-segregation aspects of self-grown catalyst nanoparticles in perovskites" Nat. Commun., 8, 15967 (2017).

32. Y. F. Sun, Y. Q. Zhang, J. Chen, J. H. Li, Y. T. Zhu, Y. M. Zeng, B. S. Amirkhiz J. Li, B. Hua, and J. L. Luo, "New Opportunity for in Situ Exsolution of Metallic Nanoparticles on Perovskite Parent" Nano Lett., 16, 5303 (2016).

33. L. Thommy, O. Joubert, J. Hamon, and M.-T. Caldes, "Impregnation versus exsolution: Using metal catalysts to improve electrocatalytic properties of LSCM-based anodes operating at $600^{\circ}$ C" Int. J. Hydrogen Energy, 41, 14207 (2016).

34. W. Zhang and W. Zheng, "Exsolution-Mimic Heterogeneous Surfaces: Towards Unlimited Catalyst Design" ChemCatChem, 7, 48 (2015).

35. D. Neagu, T. S. Oh, D. N. Miller, H. Menard, S. M. Bukhari, S. R. Gamble, R. J. Gorte, J. M. Vohs, and J. T. Irvine, "Nano-socketed nickel particles with enhanced coking resistance grown in situ by redox exsolution" Nat Commun, 6, 8120 (2015).

36. J. Zhou, T.-H. Shin, C. Ni, G. Chen, K. Wu, Y. Cheng, and J. T. S. Irvine, "In Situ Growth of Nanoparticles in Layered Perovskite $\mathrm{La}_{0.8} \mathrm{Sr}_{1.2} \mathrm{Fe}_{0.9} \mathrm{Co}_{0.1} \mathrm{O}_{4-\delta}$ as an Active and Stable Electrode for Symmetrical Solid Oxide Fuel Cells" Chem. Mater, 28, 298 (2016).

37. Y. Sakito, A. Hirano, N. Imanishi, Y. Takeda, O. Yamamoto, and Y. Liu, "Silve infiltrated $\mathrm{La}_{0.6} \mathrm{Sr}_{0.4} \mathrm{Co}_{0.2} \mathrm{Fe}_{0.8} \mathrm{O}_{3}$ cathodes for intermediate temperature solid oxide fuel cells" J. Pow. Sour., 182, 476 (2008).

38. C. Sun, R. Hui, and J. Roller, "Cathode materials for solid oxide fuel cells: a review" J. Solid State Electrochem., 14, 1125 (2009).

39. J. Zhang, Y. Ji, H. Gao, T. He, and J. Liu, "Composite cathode $\mathrm{La}_{0.6} \mathrm{Sr}_{0.4} \mathrm{Co}_{0.2} \mathrm{Fe}_{0.8} \mathrm{O}_{3}$ $\mathrm{Sm}_{0.1} \mathrm{Ce}_{0.9} \mathrm{O}_{1.95} \mathrm{Ag}$ for intermediate-temperature solid oxide fuel cells" J. All. Comp., 395, 322 (2005).

40. S. Uhlenbruck, F. Tietz, V. Haanappel, D. Sebold, H.-P. Buchkremer, and D. Stver, "Silver incorporation into cathodes for solid oxide fuel cells operating at intermediate temperature" J. Solid State Electrochem., 8, 923 (2004).

41. W. Zhou, Z. Shao, F. Liang, Z.-G. Chen, Z. Zhu, W. Jin, and N. Xu, "A new cathode for solid oxide fuel cells capable of in situ electrochemical regeneration" J. Mater Chem., 21, 15343 (2011)

42. L. Fan, M. Chen, H. Zhang, C. Wang, and C. He, " $\mathrm{Pr}_{2} \mathrm{NiO}_{4}-\mathrm{Ag}$ composite as cathode for low temperature solid oxide fuel cells: Effects of silver loading methods and amounts" Int. J. Hydrogen Energy, 42, 17544 (2017).

43. J. Llorca, A. Needleman, and S. Suresh, "An analysis of the effects of matrix void growth on deformation and ductility in metal-ceramic composites" Acta Metallurgica et Materialia, 39, 2317 (1991). 
44. L. Rørmark, K. Wiik, S. Stølen, and T. Grande, "Oxygen stoichiometry and structural properties of $\mathrm{La}_{1-\mathrm{x}} \mathrm{A}_{\mathrm{x}} \mathrm{MnO}_{3 \pm \delta}(\mathrm{A}=\mathrm{Ca}$ or $\mathrm{Sr}$ and $0 \leq \mathrm{x} \leq 1)$ " J. Mater. Chem., 12 1058 (2002).

45. M. J. Jørgensen and M. Mogensen, "Impedance of Solid Oxide Fuel Cell LSM/YSZ Composite Cathodes" J. Electrochem. Soc., 148, A433 (2001).

46. S. Koch, C. Graves, and K. V. Hansen, Elchemea Analytical DTU Energy2018 [Available from: https://www.elchemea.com/.

47. K. Kammer Hansen, M. Menon, J. Knudsen, N. Bonanos, and M. Mogensen, "The Effect of a CGO Barrier Layer on the Performance of LSM/YSZ SOFC Cathodes" J. Electrochem. Soc., 157, B309 (2010).

48. S. B. Adler, J. A. Lane, and B. C. H. Steele, "Electrode Kinetics of Porous MixedConducting Oxygen Electrodes" J. Electrochem. Soc., 143, 3554 (1996).

49. R. Küngas, F. Bidrawn, E. Mahmoud, J. M. Vohs, and R. J. Gorte, "Evidence of surface-reaction rate limitations in SOFC composite cathodes" Solid State Ionics, 225, $146(2012)$
50. Y. Takeda, R. Kanno, M. Noda, Y. Tomida, and O. Yamamoto, "Cathodic Polarization Phenomena of Perovskite Oxide Electrodes with Stabilized Zirconia" J. Electrochem. Soc., 134, 2656 (1987)

51. E. Siebert, A. Hammouche, and M. Kleitz, "Impedance spectroscopy analysis of $\mathrm{La}_{1-\mathrm{x}} \mathrm{Sr}_{\mathrm{x}} \mathrm{MnO}_{3}$-yttria-stabilized zirconia electrode kinetics" Electrochimica Acta, 40, 1741 (1995).

52. N. L. Robertson and J. N. Michaels, "Double Layer Capacitance of Porous Platinum Electrodes in Zirconia Electrochemical Cells" J. Electrochem. Soc., 138, (1991).

53. R. Millini, M. F. Gagliardi, and G. Piro, "Structure, stoichiometry and phase purity of strontium-doped lanthanum manganite powders" J. Mater. Sci., 29, 4065 (1994).

54. R. D. Shannon, "Revised effective ionic radii and systematic studies of interatomic distances in halides and chalcogenides" Acta Crystallographica Section A, 32, 751 (1976). 